\section{犬の外耳炎汇対するブレドニソロ 製刘の応用}

\author{
森建 樹*
}

犬の外耳炎は慢性化しやすい疾患であり，きわめて悪 質なものは外科的治療法より他にない。しかしながら近 時その治療薬として, 外耳炎専用軟膏 (オチュール三昭) やエアゾリンDなどが出現して好成績を収めることがで きるようになったが，前記の軟膏は注入後患犬が耳を左 右に振った場合, 溶けた薬郕が四散して飼主や獣医師の 被服を污染し，また室内をも污染して極めて始末が悪 く，その上チューブ入りのため注入量の測定がむずかし いなぞの欠点があった．またさきに武田薬品より発売さ れたェアゾリンDはきわめて有効な成績をあげている が，噴霧に際して独特の噴射音を発するため憶病な犬に 対して使用することができなかった。

そこで何かこれらの薬剤に代るべきものがないものか と物色していたところ，たまたま人医界で好評を博して いる耳科用プレデックス液のあることを知り，これを早 速使用してみたところ好成績を挙げることができた。そ の概要について報告する.

\section{1. 本 質}

本剂は 1cc中に次の成分を含有する白色のきわめて安 定な水性懸濁液である。

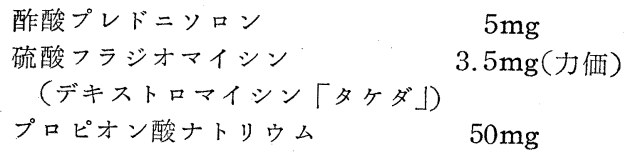

な拉，本剤は抗菌性物質製剤基準に適合するものであ る.

\section{2. 用法和よび用量}

本郕を外耳に使用する際, 墨臭ある分泌物多量に蓄積 している場合は綿棒にて軽く掃除して後，1回0.5 1.0 cc点耳した. 回数は 1 日 1 回または 2 回. 注入後外部よ り良くマッサージを行なった。

\section{3. 成 績}

下記の 6 例はいずれも慢性経過をとるものばかりであ

\begin{tabular}{|c|c|c|c|c|c|c|c|}
\hline No. & 種 & 類 & 性 & $\begin{array}{l}\text { 年 } \\
\text { 令 }\end{array}$ & 病状 & $\begin{array}{l}\text { 治療 } \\
\text { 回数 }\end{array}$ & 転帰 \\
\hline 1 & セッタ & - & $\hat{\delta}$ & 2 & $H$ & 5 & 治 \\
\hline 2 & セッタ & - & "I & 3 & $H$ & 4 & $"$ \\
\hline 3 & 柴 & 犬 & 우 & 7 & + & 3 & "I \\
\hline 4 & セッタ & - & $\hat{o}$ & 2 & H & 7 & $"$ \\
\hline 5 & シェパー & ド & 우 & 10 力月 & + & 2 & "I \\
\hline 6 & エアデー & M & $\hat{o}$ & 6 & H & 10 & 不治 \\
\hline
\end{tabular}

* 肢阜県 開業
った．急性症に使用した13例はいずれも 1 2 回の注入 および注射にて全治したので記載しなかった。上記のい ずれも注入の外にペニシリン，またはマイシリンの注射 を併用した．例 6 はさわめて㖦質な慢性化せるもので外 科手術による以外全治の見込みなし。

\section{むすび}

耳科用プレデックス液の添付されているスポイトはき わめて患部に注入しやすい構造になっており，また目盛 りがついているので注入量が確実に決定することができ る．注入しても患犬がいやがらず疼痛もない，それに前 述のごとき被服その他を污染することもない，犬の外耳 炎に対してきわめて効果的薬剤であると考㝋られる.

\section{軟筫塩化ビニール管を用いた 小動物の外科処置 3 題}

$$
\text { 高 瀬 一 行* }
$$

今回著者は小動物の直腸脱, 重積小腸の肚門外脱出お よび子宮脱に対して，それぞれ整復後，該部に軟質塩化 ビニール管（以下ビ管と略す）を挿入して固定し，再脱 出の防止を図ったところ，極めて良好な治療成績を得た ので, ここにその処置法および経過を報告し，小動物臨 㦿家各位のご参考に供したいと思う。

なおこの報告中，直腸脱の治験例は，第74回日本臨東 獣医学会（1961年, 近畿)において報告した.

\section{I 直 腸 脱}

1. 症例 犬 3 頭 (生後 40, 60 おょび70日), 猫 2 頭 （生後 80 および90日）合計 5 例である. 直腸脱の原因は, コクシジウム，ジアルディア，バランチジウムの原虫寄 生による下痢，および単純な大腸炎による下㢉で，発病 後 1 ～ 2 日に治療を依頼された（表 1 参照）.

2. 処置法 犬はネンブタール $0.3 \mathrm{cc} / \mathrm{kg}$ 静脈内注射 を，猫は $0.4 \mathrm{cc} / \mathrm{kg}$ 笳肉内注射で全身麻酔を行なう。脱 出した腸を生食液で洗滌したのち，プレデックス軟高を その表面に塗した．次いで患畜の両後肢を持ち上げて逆 さにつり，脱出した腸の先端部から徐々に内転するよう に押入れ，完全に整復を確認してから，予め準備してある ビ管（口径 $0.7 \sim 0.9 \mathrm{~cm}$ ，患畜の大きさにより選定）を 脱出腸の $30 \%$ 増の長さのものを肛門より徐々に插入す る. 最後に挿入ビ管を固定するために, 図 3 の A, B, C のいずれかの方法で肚門の縫合（8 号靯性絹糸）を行な って腸の再脱出を防止した。

3. 術後の経過 表1のごとくビ管の直腸内に留置し ている期間は $2 \sim 3$ 日間で自然に脱出，または半脱出と

* 大阪市 開業 
表 1 直 腸 脱 治 験 成 績 表

\begin{tabular}{|c|c|c|c|c|c|c|c|c|c|c|c|c|c|}
\hline \multirow[b]{2}{*}{ 番号 } & \multirow{2}{*}{$\begin{array}{l}\text { 畜種特 } \\
\text { よび種 } \\
\text { 類 }\end{array}$} & \multirow[b]{2}{*}{ 性 } & \multirow{2}{*}{$\begin{array}{l}\text { 年 } \\
\text { 令 } \\
\text { 昌 }\end{array}$} & \multirow{2}{*}{$\begin{array}{c}\text { 体 } \\
\text { 重 } \\
(\mathrm{kg})\end{array}$} & \multicolumn{3}{|r|}{ 現 } & 症 & \multicolumn{2}{|r|}{ 処 } & 置 & \multirow{2}{*}{$\begin{array}{l}\text { ビ管 } \\
\text { 在腸 } \\
\text { 日数 }\end{array}$} & \multirow{2}{*}{$\begin{array}{l}\text { 治 転 } \\
\text { 療 } \\
\text { 日 } \\
\text { 数 㷌 }\end{array}$} \\
\hline & & & & & $\begin{array}{l}\text { 下叔 } \\
\text { 日数 }\end{array}$ & $\begin{array}{l}\text { 直腸 } \\
\text { 脱日 } \\
\text { 数 }\end{array}$ & $\begin{array}{l}\text { 腸脱出 } \\
\text { の長さ } \\
\mathrm{cm}\end{array}$ & 下痢の原因 & $\begin{array}{l}\text { 挿入した } \\
\text { ビ管口径 } \\
\text { /長さcm }\end{array}$ & $\begin{array}{l}\text { 肛門縫 } \\
\text { 合法 } \\
\text { (図 3) }\end{array}$ & 薬物桼よび食事療法 & & \\
\hline 1 & (三河) & 우 & 40 & 2.1 & 5 & 2 & 3.0 & コクシジウム & $0.9 / 4.0$ & A & $\begin{array}{l}\text { (1) } 10 \sim 20 \mathrm{cc} 5 \text { 回皮下注射 } \\
\text { (2) } 0.2 \sim 0.3 \quad 7 \text { 日 } \\
\text { (5) } 200 \sim 300 \mathrm{cc}\end{array}$ & 3 & 7 治 \\
\hline 2 & (突河) & $\hat{o}$ & 60 & 3.5 & 7 & 1 & 1.5 & バランチジウム & $0.9 / 3.0$ & A & $\begin{array}{l}\text { (1) } 10 \sim 20 \mathrm{cc} 4 \text { 回皮下注射 } \\
\text { (3) } 0.3 \sim 1.0 \mathrm{~g} 8 \text { 日 } \\
\text { (5) } 200 \sim 300 \mathrm{cc}\end{array}$ & 3 & 8 治 \\
\hline 3 & 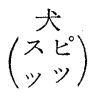 & 우 & 70 & 3.0 & 10 & 1 & 5.0 & ジアルディア & $0.9 / 6.5$ & B & $\begin{array}{l}\text { (1) } 10 \sim 20 \mathrm{cc} 8 \text { 回皮下注射 } \\
\text { (3) } 0.3 \sim 1.0 \mathrm{~g} 10 \text { 日 } \\
\text { (5) } 200 \sim 300 \mathrm{cc}\end{array}$ & $2^{2} / 3$ & 10 治 \\
\hline 4 & 猫 & 우 & 80 & 0.7 & 8 & 1.5 & 4.0 & 大 腸 炎 & $0.7 / 5.0$ & $\mathrm{C}$ & $\begin{array}{l}\text { (1) } 10 \mathrm{cc} 7 \text { 回皮下注射 } \\
\text { (4) } 1.0 \sim 2.0 \mathrm{~g} 8 \text { 日 } \\
\text { (5) } 80 \sim 100 \mathrm{cc}\end{array}$ & $2^{1 / 2}$ & 8 治 \\
\hline 5 & 猫 & $\hat{o}$ & 90 & 0.8 & 7 & 1.5 & 7.0 & コクシジウム & $0.7 / 9.0$ & $\mathrm{C}$ & $\begin{array}{l}\text { (1) } 10 \mathrm{cc} 7 \text { 回皮下注射 } \\
\text { (2) } 0.2 \sim 0.37 \text { 日 } \\
\text { (5) } 80 \sim 100 \mathrm{cc}\end{array}$ & $2^{1 / 2}$ & 7 治 \\
\hline
\end{tabular}

注：(1) $10 \%$ ブドウ糖液加複合ビタミン注射 (2) ロメジン末日量拉よび投与日数 (3) エンテロヴィオフオルム末日 量および投与日数 (4)エンテロマイシン末日量および投与日数 (5) 籃節および野菜スープと重湯等量混合日量
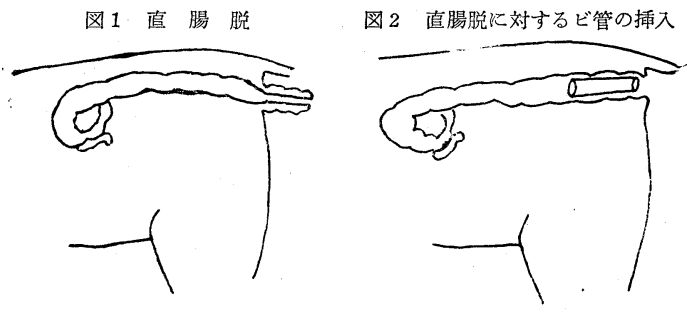

図 3 肛門汇括けるビ管の固定法

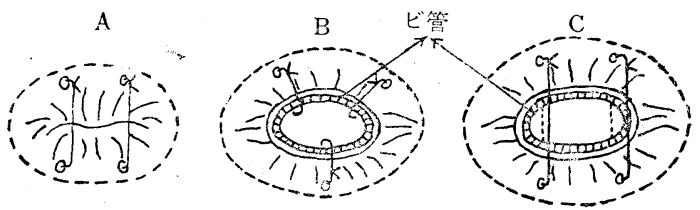

なった．これは肚門組織が綟系縫合に対して弱いためで ある。しかしながらビ管が脱出しても腸管の再脱出はな かった.

\section{II 重皘小腸の肛門外脱出}

1. 症例 畜主, 大阪市生野区新今里町七丁目 21 浜 本 実 雑種犬 9 \% 6 力 $12 \mathrm{~kg}$

2. 禀告 昭和 36 年 7 月 23 日, 夕刻突然唱吐し, そ水 以降食欲全廃し，元気がない，24日朝，肛門外に赤い脱 出物を見たが昼頃には消退していた．排便はないが便意 を催すと肛門より赤い脱出物を見る。水を少量づつ飲を が，黄褐色水様の嵒吐を反復している．27日朝から肛門 の脱出物は出たままとなり, 同日午後 7 時治療を求めら れた。

3. 現症 患犬は栄養が不良で被毛は光沢がなく，露 出粘膜は蒼白となり, 口腔内はやや乾燥しているが飲思
はない，径 $4.0 \mathrm{~cm}$ ，長さ $9.0 \mathrm{~cm} の$ 腸の肛門外脱出が見ら れ, 脱出部は発赤腫脹して, 土砂が附着し粘膜の損傷が 著るしい，とくに先端部は暗紫赤色を呈している.

腹部を触診すると背椎下部において中腹部より骨盤腔 内に向い，やや硬い腸管を探知した。この所見から単純 な直腸脱ではなく，重積小腸の肛門外脱出と診断した (図 4 ).

4. 手術 全身麻酔を汪どこし，先ず脱出した腸を生 食液で洗滌しプレデックス軟高を表面に叙布したのち， 型のごとく開腹術を行なった．腹膜には著変がなく，や

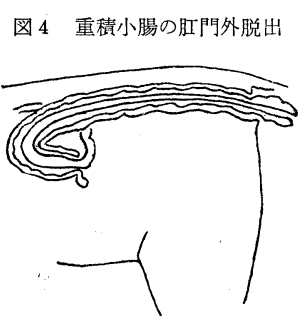

図 5 重積小腸の肛門外脱出飞対寸 るビ管の插入

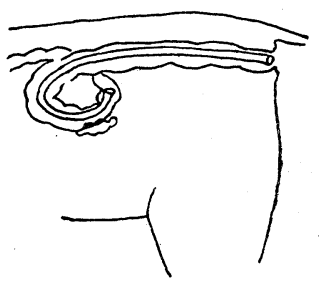

や赤色を帯びた腹水の貯溜があり，大網膜に軟度の充血 を認め，その下に大腸が隆起していた。

回盲弁部を起点として大腸内に回腸が嵌入し，大腸は このため硬結隆起し暗赤色を呈していた．盲腸は嵌入口 に押し付けられ，先端部は腫大しリンパ沪胞が透視され た。

回盲弁部を保持して徐々に嵌入した腸管を整復した。 嵌入した小腸腸間膜は白色義膜状を呈し, 嵌入小腸は黒 褐色に変じ，柔軟性を失って硬変し，所々に狭窄輪を現 わしていた．完全整復後，先ず肛門からカテーテルを用 い微温生食液で洗腸し, 次いで図 5 のように径 $1.5 \mathrm{~cm}$ の

日獣会誌 15 (1962) 
表 2 重積小腸の肛門脱出症例の経過

\begin{tabular}{|c|c|c|c|c|c|c|}
\hline 病日 & 腸脱出状態 & $\begin{array}{l}\text { ビ匴在 } \\
\text { 腸期間 }\end{array}$ & 领思食欲 & $\begin{array}{l}\text { 嘔心 } \\
\text { 澏吐 }\end{array}$ & 排 & 置 \\
\hline 1 & & & \pm- & H & + & \\
\hline 2 & $\begin{array}{l}\text { 腸脱出戣見自 } \\
\text { 然济入 }\end{array}$ & & \pm- & H & - & \\
\hline 3 & $\begin{array}{l}\text { 便意を催すと } \\
\text { 总出し然に } \\
\text { 還入する }\end{array}$ & & \pm- & $H$ & - & \\
\hline 4 & $\begin{array}{l}\text { この状態を反 } \\
\text { 復する }\end{array}$ & & \pm- & H & - & \\
\hline 5 & 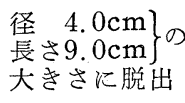 & 22.00 & \pm- & H & $\begin{array}{l}+ \\
\text { 術後洗腸水流 } \\
\text { 出する }\end{array}$ & 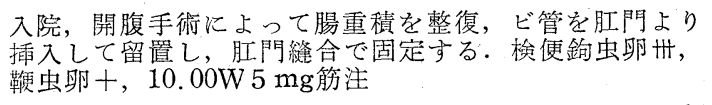 \\
\hline 6 & & 59 時間 & $\begin{array}{l}\stackrel{+}{+} \\
20.00 \\
\text { 流動食 }\end{array}$ & - & $\begin{array}{l}\text { 色 } \\
10.00 \text { 褐色粘血便 } \\
16.00 \text { 褐色水椂便 }\end{array}$ & $\begin{array}{l}12.004 \text { 程化エチレン } 5.4 \mathrm{~g} \text { 球 } 10 \text { 球投与. } 14.00 \text { 流マ } 10 \% \\
\text { 液 } 120 \mathrm{cc} \text { 投与. } 16.00, \text { 鈎虫 } 75 \text { 匹, 未成熟回虫 } 2 \text { 匹排出. } \\
18.00 \mathrm{~W} \text { mg筋注. }\end{array}$ \\
\hline 7 & & & 流動食 & - & $\stackrel{+}{+}+\frac{\text { 粘液便 }}{4}$ & W5mg 2 回筋注 \\
\hline 8 & & $\begin{array}{c}\downarrow \\
9.00\end{array}$ & 流動食 & - & 半固型便 & $\begin{array}{l}\text { ビ管除去（ビ管固定のための肛門緷合が組織断裂し半ば } \\
\text { 自然排出する) } \\
\text { W5mg } 2 \text { 回筋注 }\end{array}$ \\
\hline 9 & & & 半流動食 & 一 & - & \\
\hline 10 & & & $\begin{array}{l}\text { 州 } \\
\text { 普通食 }\end{array}$ & - & $\begin{array}{l}\stackrel{+}{+} \text { グリセリ灌腸 } \\
\text { 固形便 }\end{array}$ & 退院 \\
\hline 11 & & & & - & - & \\
\hline 12 & & & 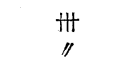 & - & $\stackrel{+}{+}$ & 腹壁の縫合部抜系 \\
\hline
\end{tabular}

注：Wはウィンタミン，10.00〜14.00はその日の時間を表わす，その他リンゲル氏液，ブドゥ糖液，ビタミン剤， ペニシリン注射，アクロマイシンの内服は省略する.

ビ管を回盲弁部から 7〜 $8 \mathrm{~cm}$ 回腸部に突出するように肛 門から徐々に插入した。この插入にあたり回盲弁部で強 い抵抗を感じたが，これはビ管が腸管内で曲折すること なく留置されるために効果的であったと考える.

再度生食液で㭔入したビ管を通じ洗腸を行なったの ち, ビ管の肛門外の残部を切除して，切口を肛門内に納 め, 次でビ管の脱出防止のため固定縫合を行なった（図 3 のB). 最後に腹壁を縫合して手術を完了した.

5. 経過 術後の経過は表 2 に示すとおり嘔心, 嘔吐 は全く消失し，術後14時間目に行なった鈎虫駆除による 虫体や, 腸内容物はビ管を通じて順調に排出され, また 怒責, 疝痛症状を現わすことなく良好な経過をとった。

とくに腸管内にビ管を留置してあるときに投与した硫 酸マグネシア，10\%液，120cc は何んの異状もなくビ管 を通じて本来の薬理作用を呈した。しかし投与から下痱 の時間は普通の場合より1時間位早いようであった。こ れは回盲弁から肛門まではビ管で流出したことになるの で,むしろ理の当然といい得るかも知れない.

\section{III 犬の子宮 脱}

1. 症例 大阪市東成区深江中 5 丁目, 東宝製鑵 テリア雑1才 雌 $8 \mathrm{~kg}$ 初産
2. 禀告 昭和 36 年 9 月 13 日, 午前 6 時頃より分婏を 始め 8 時半頃までに 4 仔を産出する. その後子宮が脱出 し始め次第に大きを增し盛んに出血するので 9 時加療を 求められる.

3. 現症 栄湌中等, 被毛光沢なし, 露出粘膜蒼白, 速脈, 呼吸速迫で, 不安状態を呈し全身血液で污染して いる．外陰部には大人拳大の双角状に反転した子宮を露 出する. 双角の左側はやや大きく笑出し, その中心孔か ら盛んに出血していた（図6).

4. 処置 患犬は出血多量のため先ず止血剤を注射 し, 次いでネンブタール $0.3 \mathrm{cc} / \mathrm{kg}$ の静脈注射で浅い全身 麻酔を行なった，脱出子宮をリンゲル液で洗滌後，アク ロマイシン軟膏を十分に塗布したのち，両後肢を吊り上 げ双角部より徐々に脱出子宮の還納を行なら。患犬は怒 責することなく容易に還納することができた。

整復後, 長さ $20 \mathrm{~cm}$, 径 $1.5 \mathrm{~cm}$ のビ管を図 7 のように 子宮内に挿入し，図8のようにビ管を固定の目的で陰唇 に縫合して手術を完了した・術後ペニシリン 30 万単位抒 よびピツイトリン $0.5 \mathrm{cc} の$ 注射を行なった。

5. 経過隔日に来院を指示したが，術後6.日目に初 めて来院した，そのときの所見は患犬は元気，食欲とも に旺盛で, 仔犬も元気に保育されている. 外陰部には污 


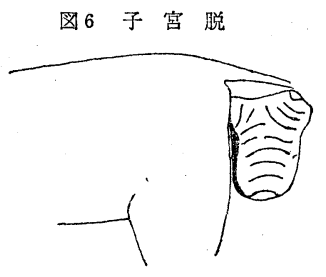

物の流出が見られない，陰唇 縫合の左側は縫合綟糸で断裂 し, 辛らじてビ管の固定は残 った右例陰唇で保持されてい た。

腹部触診で子宮が縮小し， 完全に整復していることをた しかめてから抜糸と同時にビ管を除去した．ビ管の内腔 には污物の附着がなく内膜炎 の併発がないものと診断し た.

ビ管插入による排尿障害も みられず，約 1 カ月後も何ん の異状も遺すことはなかっ た。

図 7 子宮脱化対するビ管插入

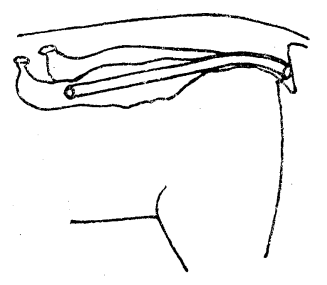

図 8 陰唇に和けるビ管固定法

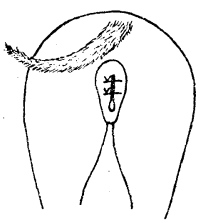

あとがき

直腸脱に対しては, 整復後, 軟質塩化ビニール管を肛門から 直腸部に，また重積小腸の肛門 外脱出に対しては開腹後, 整復 してから同じく軟質塩化ビニー ル管を肛門から回盲弁部まで插 入留置し，打の抢のその発生起点を固定することによっ て，再脱出拉よび再重積を防ぐことができた。

とくに重積小腸の肛門外脱出例に招いては重積発生後 4 日も経過し，高等の腸の変質があったが，これを整復 固定により完全に治瘉させることがでさたことは興味深 い.

なお腸管は自然の状態で整復されているので後遣症の
発生は全くないものと思われる。

子宮脱の症例に打いては整復後, 軟質塩化ビニール管 を挿入して，これを固定するため陰唇に綟系縫合を行な ったが，その離断にたいしては肛門よりはるかに強啜で あった。

軟質塩化ビニール管は腸执よび子宮内で不透明にはな ったが，硬化することなく適当に柔軟性を保持して組織 の損傷は全くみられなかった.

稿を終わるに臨み起草を针めて下さった，恩師柬胤弘 先生, 校閲を煩わしご助言下さった大阪府立大学農学部 永田教授，なにかと授助して下さった学友小林與六君， 同業の山本昌義先生汇それぞれ感謝の意を表す。

\section{最後に小動物臨床の諸先生に和願い}

記述しました小腸の肛門脱出症，すなわち回盲弁部 の重積症に対する本術式の治験例を収録致したいと考 えていますが，自然の発生を待たなければならないの で私個人では到底不可能のことで，本症を含め15年間 に 4 例でありました. 全国の小動物臨床の先生に特か れまして, 本症に遭遇致され，その上，前述の術式を お試み下さったならば，ご迷惑に存じますが，下記事 項を小生宛にご連絡賜わりますれば幸甚に存じます。

な新京阪神の先生方に手術の写真を撮らせていただ きたいと思いますが，も乙お許しを得られますような らば大阪 971〜7927 にお知らせ下さい。

\section{記}

1. 種類 2 . 年令 3 . 性 4 . 体重 5 . 発病 から手術までの日時 6 . 患部の状況（腸重積部の深 さおよび組織の変化） 7 . ビ管の太さ 8 . ビ管の 在腸時間 9 . 肛門におけるビ管の固定方法 10 . 転 帰 11 . その他.

\section{馬の白血病}

馬のリンパ性白血病は普通高年令の馬に起こる．特徴 としては急性に発症し, 病期が短い, 症状としては疝痛, 貧血, その他血液の異常, 心機能不全, 栄養不良などの いろいろな形をとる。リンパ腺の腫脤は認められる場合 も認められない場合もある。血液検査では白血球数の增 加が認められることが普通である。この場合好中球数の 増加することが多く, リンパ球数の增加する場合は多く ない。いずれにしても異常白血球と正常にない単核の細 胞が存在する．腫脹したリンパ腺細胞や他の臓器組織に 浸潤した細胞は，主としてリンパ球性の細胞で細胞分裂 像も多く多形性を示す。疫学拈よび原因については全く 不明である. (Theilen, G.H., et al., J. Amer. Vet. Med. Ass., 140,923, 1962)

\section{馬の栄養性蚠血}

春に現われる馬の貧血症の特徴は食欲が無くなること と水を飲みたがることである. 原因としてはミネラル， ビタミン, 微量元素の欠乏が考えられる. Fe, Mg 打よび $\mathrm{Na}$ を含有する薬剤による治療を行なう. (SEILs, H., Mh. Vet. Med., 17, 194,1962-Vet. Bull., 32, 619)

\section{猫の侵食性潰瘍の治療}

患畜は 7 才の去勢雄猫. 上口唇の潰瘍のため1961年 1 月に来院. 診察してみると後肢の指間にも漬瘍が発生し ていた。治療法としてゲンチアナバイオレットを 2 カ月 間潰痹部に塗布したが效果が認められなかつた。そこで 乳房炎用クロールテトラサイクリンを患部に塗布したが 無効であつた。7月に入ると上記の場所のほかに肛門下 部と後肢膝関節の上部にさらに潰瘍が発生して来た．プ レドニソロンを $10 \mathrm{mg}$ 注射後, $1 \mathrm{mg}$ を日に 2 回 10 日間経 口投与した。患部に Calamine とハイドロコーチゾン軟 膏を塗布したが無効であつた。 その後投与した Sulpha一 dimidine, ビタミン C などの薬物にも反応しなかつた ので11月から抗ヒスタミン剤である phenergan を10mg 日に2 回 2 週間投与し Calamine と benadryl 軟辜を塗 布したところ後肢の潰瘍は反応を示したが他の部分は反 応せずむしろ進行した。 そこで1962年 2 月に Betamethasone $0.25 \mathrm{mg}$ づつに 2 回 4 日間経口投与を続け, その後はその半量を 6 日間投与し，さらにこの薬物とネ オマイシンを含有する軟高を患部に叙布したところ急速 に治瘾した. (R.H. PalmeR, Vet. Rec., 74, 924, 1962) 